\title{
Commodity prices and the CPI: Cointegration, information, and signal extraction
}

\author{
R.A. Pecchenino * \\ Department of Economics, Michigan State University, East Lansing, MI 48824-1038, USA
}

\begin{abstract}
This paper provides theoretical underpinnings for the commodity price/aggregate price relationship, discusses the conditions under which commodity prices are useful information variables for monetary policy, and provides empirical results which suggest why commodity prices have not been very useful for forecasting.
\end{abstract}

Keywords: Commodity price indices, Inflation forecasts, Cointegration.

\section{Introduction}

Recently there has been much interest expressed by policy practitioners [Angell (1987); Whitt (1988); DeFina (1988); Garner (1989); Furlong (1989)], academics [Boughton and Branson (1988); Hall (1982); Baillie (1989)] and private sector financial analysts [Brittan (1988); Kudlow (1988)] in the use of commodity price indices as indicators of monetary policy. Much of this interest arises from the observation that commodity price indices appear to lead the consumer price index (CPI), and so may signal inflationary expectations and therefore be useful in producing better forecasts of future inflation. Intuitively, changes in inflationary expectations should appear as changes in commodity prices prior to being reflected in changes in the CPI because commodity markets are speculative auction markets in which prices immediately adjust to changes in information, while many prices comprising the

\footnotetext{
* I would like to thank Richard Baille and Robert Rasche for their advice and encouragement, and Michael Redfearn for his excellent research assistance. All remaining errors are mine alone.
}

CPI respond to inflationary expectations with a lag. If this is the case, a signal of inflationary expectations emanating from the commodity markets could provide the monetary authority with information which can be used to reduce price level volatility.

While an apparent correlation between commodity price indices and the CPI seems plausible, little empirical evidence supports the contention that the information in commodity prices can be used effectively to forecast the CPI or to adjust monetary policy. For example, Baillie (1989), Boughton and Branson (1988), and Garner (1989) find that there is no discernible long-run relationship between commodity prices and the CPI (the two time series are not cointegrated), yet Boughton and Branson (1988) and Garner (1989) find a weak short-run relationship (commodity prices help predict future consumer price inflation) while Baillie (1989) does not. Whitt (1988) suggests that there is not only a long-run relationship, but that commodity prices should be an intermediate target of monetary policy. This suggestion is contested by Garner (1989), and by Kitchen, Conway, and LeBlanc (1990) who claim that monetary policy directed at controlling com- 
modity prices could cause real economic disruption in agricultural markets, although they find no linkage between commodity prices and monetary policy that could be exploited. DeFina's (1988) review of the literature leads him to the same conclusion.

A motivation for this paper is to provide a theoretical foundation for long- and short-run relationships between commodity and consumer prices, and to then use the theoretical results to suggest a unifying interpretation of the disparate empirical findings. The paper develops a simple two-sector rational expectations model in which commodity prices may be informative about the CPI, defined as the price of manufactures. The model follows Fischer (1977) and Gray (1976) in that wages in the manufacturing sector are determined by long-term contracts while commodity prices are determined in speculative auction markets.

The major findings of this analysis are as follows. First, if the CPI is nonstationary, then a likely source of this nonstationarity is the monetary policy regime. This result is consistent with Pecchenino and Rasche (1990) and Goodfriend (1987). Second, while the model suggests that there is a close relationship between commodity and aggregate prices, commodity and aggregate prices will be cointegrated only under certain assumptions on the money supply rule or on the stochastic processes generating the demand and supply shocks to the system. Various empirical tests provide weak support for the hypothesis that commodity prices and the CPI are cointegrated. Third, even if a long-run relationship between consumer and commodity prices does not exist, the information in commodity prices may be useful for forecasting future consumer prices. However, signal extraction problems mitigate against using commodity prices to set monetary policy.

\section{The model}

The model is an adaptation of the FischerGray model of long-term contracts. It is devised to capture linkages between commodity prices and the CPI by including a commodity sector as well as a manufacturing sector. A well-known feature of the Fischer-Gray model is that monetary policy can be cffective in smoothing out unforeseen shocks to the system. This feature is maintained in this extension even if consumer prices are observed with a lag so long as the monetary authority can respond to the information in commodity prices before private sector agents can renegotiate their long-term contracts.

Consider the following two sector economy. In sector 1 manufactured goods are produced by firms using a Cobb-Douglas technology with two factors of production, labor and commodities. In sector 2 commodities are produced using a fixed factor (which is subsumed in the analysis). Labor contracts set the nominal wage one period in advance, and so labor at time $t$ is demand determined. Commodity markets are assumed to clear in each period. Consumer demand is represented by a quantity equation, and, as consumers demand manufactures only, the price of manufactures represents the CPI. The monetary authority sets the money supply according to a deterministic rule which depends only on publicly available information. Both private sector individuals and the monetary authority have the same information set at any time $t$, and agents are assumed to form rational expectations.

\subsection{The manufacturing sector}

The Cobb-Douglas production function for the representative profit-maximizing firm is

$y_{t}=\alpha \ell_{t}^{d}+(1-\alpha) c_{t}^{d}+\mu_{t}$,

where $\alpha \in(0,1), y$, is the logarithm of output of manufactures at time $t, \ell_{i}^{d}$ is the logarithm of labor demand, $c_{t}^{d}$ is the logarithm of demand for commodities, and $\mu_{t}$ is a random variable.

The representative firm demands commodities until the marginal product of commodities equals the real price of commodities,

$g_{t}-p_{t}=\ln (1-\alpha)-\alpha c_{t}^{d}+\alpha \ell_{t}^{d}$,

where $g_{t}$ is the logarithm of the nominal price of commodities, and $p_{t}$ is the logarithm of the price of manufactures (the price level). It demands labor until labor's marginal product equals the real wage,

$w_{t}-p_{t}=\ln \alpha+(1-\alpha) c_{t}^{d}-(1-\alpha) \ell_{t}^{d}$,

where $w_{t}$ is the logarithm of the wage. Assume that the logarithm of labor supply is an increasing 


\section{دريافت فورى ـ ـ متن كامل مقاله}

\section{ISIArticles}

مرجع مقالات تخصصى ايران

ل امكان دانلود نسخه تمام متن مقالات انكليسى ل امكان دانلود نسخه ترجمه شده مقالات ل يذيرش سفارش ترجمه تخصصى $\checkmark$ ل امكان جستجو در آرشيو جامعى از صدها موضوع و هزاران مقاله ل امكان دانلود رايكان r صفحه اول هر مقاله

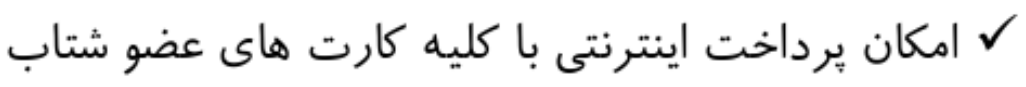
ل دانلود فورى مقاله پِ از برداخت آنلاين

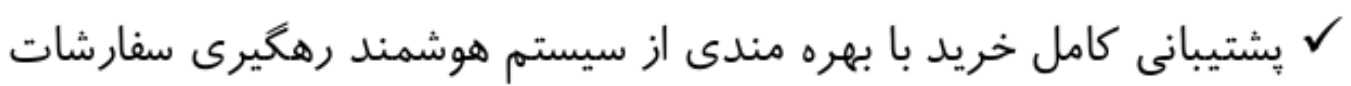

